\title{
THE STRUCTURE AND MORPHOLOGY OF THE SURFACE OF DUPLEX LAYERS AFTER SATURATION OF THE BASE LAYER WITH CARBON
}

\author{
STRUKTURA IN MORFOLOGIJA POVRŠINE DUPLEKS PLASTI \\ PO NASIČENJU OSNOVNE PLASTI Z OGLJIKOM
}

\author{
Wladyslaw Skoneczny \\ University of Silesia, Ul. Żytnia 10, 41-200 Sosnowiec, Poland \\ Wladyslaw.Skoneczny@us.edu.pl \\ Prejem rokopisa - received: 2015-05-29; sprejem za objavo - accepted for publication: 2015-12-15
}

doi: $10.17222 /$ mit.2015.108

\begin{abstract}
The paper presents a new method of obtaining aluminium-oxide-based, duplex-type layers. In the first stage, the base layer is produced via the hard anodising of aluminium alloys in order to obtain the optimal structural and morphological properties. Following anodising, the samples with an $\mathrm{Al}_{2} \mathrm{O}_{3}$ layer are rinsed in distilled water in order to remove the electrolyte. Graphite was introduced into the structure of aluminium oxide during a thermal treatment in a solid medium consisting of graphite dust. Afterwards, the properties of the obtained layers were determined using a scanning electron microscope, a transmission electron microscope and an atomic force microscope (AFM), as well as X-ray diffraction. The structure of the duplex-type layers contains carbon and other precipitates, which are typical for an alloy with additions of $\mathrm{Fe}, \mathrm{Mn}, \mathrm{Cr}$ and other elements. Carbon precipitates have a relatively weak connection with the matrix, as an envelope with numerous discontinuities forms around each carbon precipitate. Carbon precipitates are considerably larger than alloy precipitates, have micrometre dimensions, occur in groups and are composed of small grouped nanometric particles that form larger agglomerates. This means that there are nanometric particles inside the micrometric ones.
\end{abstract}

Keywords: aluminium alloys, nano-layers, SEM, AFM, EDS

Članek predstavlja novo metodo za izdelavo dupleksne plasti aluminijevega oksida. V prvi stopnji se izdela osnovna plast s trdim anodiziranjem aluminijevih zlitin, da se dobi optimalno strukturo in morfološke lastnosti. Po anodizaciji so vzorci z $\mathrm{Al}_{2} \mathrm{O}_{3}$ plastjo potopljeni v destilirano vodo, da se izpere elektrolit. V strukturo aluminijevega oksida se uvede grafit med toplotno obdelavo v trdem mediju, ki je vseboval grafitni prah. Potem so bile določene lastnosti dobljenih plasti, s pomočjo vrstičnega elektronskega mikroskopa, presevnega mikroskopa in mikroskopa na atomsko silo (AFM), kot tudi z rentgensko difrakcijo. Struktura dupleksnih plasti je vsebovala izločke ogljika in druge izločke, ki so značilni za zlitine, $\mathrm{z}$ dodatkom $\mathrm{Fe}, \mathrm{Mn}, \mathrm{Cr}$ in drugih elementov. Izločki ogljika imajo relativno šibko povezavo z osnovo, saj nastaja okrog vsakega izločka ogljika ovojnica s številnimi diskontinuitetami. Izločki ogljika so mnogo večji kot izločki zlitin, imajo mikrometrske dimenzije, se pojavljajo v skupinah in so sestavljeni iz malih gruč nanometričnih delcev, ki tvorijo večje skupke. To pomeni, da so znotraj mikrometrskih delcev prisotni nanometrski delci.

Ključne besede: aluminijeve zlitine, nanoplasti, SEM, AFM, EDS

\section{INTRODUCTION}

Aluminium alloys and the composite layers formed on them are widely used in engineering (components of heat engines and power machines, in aircraft and space industries) owing to their very good thermal conductivity, low density and high strength.

Oxide layers obtained via hard anodising may, to a large degree, change their properties, depending on the process conditions. Thanks to their characteristic porous structure, $\mathrm{Al}_{2} \mathrm{O}_{3}$ layers can be used in a number of technology fields. Oxide coatings have been used in surface engineering as protective-decorative or electro-isolating layers for many years. In recent years, $\mathrm{Al}_{2} \mathrm{O}_{3}$ layers have been used for the sliding couples in heat engines: ${ }^{1-6}$

- cylinder bearing surfaces in lubricant-free compressors,

- combustion-engine pistons,

- cylinder bearing surfaces in lubricant-free pneumatic servo-motors,
- shock-absorber components.

One of the most recent applications of oxide layers are the moulds used for producing nano-elements with a diameter of 4-200 nm. ${ }^{7}$

Machine components produced from aluminium or its alloys with a specially prepared surface layer are used more and more frequently. The main arguments for broadening the scope of applications for aluminiumoxide-based, duplex-type layers in surface engineering are as follows:

- easy access to devices and very inexpensive operation,

- the possibility of conducting a surface treatment on all Al groups and its alloys,

- high efficiency of the duplex-type treatment,

- the possibility of obtaining electro-isolating and protective-decorative coatings, as well as hard, abrasionresistant layers,

- satisfactory quality of the surface after processing, 
- the possibility of forming surface layers with a gradient, composite and, first of all, an amorphous structure.

The wear of materials used in machine building takes place mostly on the surface and determines the operational durability of a given appliance. The past few years have been a period of intensive development in state-of-the-art, duplex, hybrid technologies. It seems that only a combination of different surface-engineering technologies, which is the foundation of the duplex technology can lead to surfaces with versatile qualities that are to meet the requirements of modern technology. As the name indicates, the duplex technology involves a sequential application of two defined surface-engineering technologies to produce a surface composed of combined properties, unattainable by any other individual form of surface engineering.

This paper presents a wide range of possibilities to shape the properties of aluminium-oxide-based surface layers using the duplex method.

For technological reasons, hard anodising is applied for lubricant-free sliding couples. The most widespread method so far has been anodising in sulphuric or oxalic acids at lowered temperatures, from $263 \mathrm{~K}$ to $278 \mathrm{~K}$, depending on the type of electrolyte. Therefore, research has been conducted for years on anodizing at elevated temperatures. The purpose of the research has been to apply such an electrolyte that would make it possible to obtain hard oxide layers at room temperature. Elimination of the electrolyte cooling stage would considerably reduce the cost of producing oxide coatings. It would be possible if hard anodising could be conducted at temperatures of 293-313 K and higher. At the same time, coatings with better properties could be obtained owing to the $\mathrm{Al}_{2} \mathrm{O}_{3}$ oxide phase transition at a temperature of $293 \mathrm{~K}$. An increase in temperature accompanying the oxidation process is conducive to etching aluminium oxide fibres. As a consequence, an oxide cell of a more regular (ideal) structure is formed. ${ }^{1,8,9}$ Increasing the electrolyte temperature would also have a considerable effect on the porosity of the oxide coating. ${ }^{1-4}$ The porosity of the obtained oxide layers is of major importance to their utilisation for a sliding interaction with plastic materials.

Adding organic substances with surface-active properties to the electrolyte has a large influence on the mechanism of the formation of oxide coatings on aluminium. The mechanism of the influence of organic substances depends on the properties of the addition and on the composition and properties of the electrolyte. A supposition can be made that under proper conditions, surface-active substances fully or partly cover the surface of the anode (on active places), as a result of which the oxidation of aluminium is considerably hindered. On the other hand, the adsorption of organic substances at the anode - the electrolyte interface causes the secondary dissolution of the layer by the electrolyte to stop. The role of this mechanism is performed precisely by the addition of the above-mentioned organic (dicarboxylic) acids. The method developed in the Division of Upper Layer Technologies, University of Silesia, does not require cooling and the process heat is used to control the properties of the obtained oxide coatings. Controlling anodising parameters allows, within some limits, programming the selected functional properties of future upper layers. ${ }^{3-12}$

The above-mentioned method consists of oxidising aluminium and its alloys in three-component electrolytes. Dicarboxylic acid is added to the mixture of sulphuric and oxalic acids. These acids have an aliphatic chain of various lengths in their structure and are arranged in a row:

1) malonic acid - $\mathrm{CH}_{2}(\mathrm{COOH})_{2}$

2) succinic acid - $\left(\mathrm{CH}_{2}\right)_{2}(\mathrm{COOH})_{2}$

3) glutaric acid - $\left(\mathrm{CH}_{2}\right)_{3}(\mathrm{COOH})_{2}$

4) adipic acid $-\left(\mathrm{CH}_{2}\right)_{4}(\mathrm{COOH})_{2}$

5) pimelic acid $-\left(\mathrm{CH}_{2}\right)_{5}(\mathrm{COOH})_{2}$

6) suberic acid $-\left(\mathrm{CH}_{2}\right)_{6}(\mathrm{COOH})_{2}$

7) azelaic acid $-\left(\mathrm{CH}_{2}\right)_{7}(\mathrm{COOH})_{2}$

8) sebacic acid $-\left(\mathrm{CH}_{2}\right)_{8}(\mathrm{COOH})_{2}$

9) phthalic acid $-\mathrm{C}_{6} \mathrm{H}_{4}(\mathrm{COOH})_{2}$.

\section{EXPERIMENTAL PART}

The hard anodising method developed in the Division of Upper Layer Technologies, University of Silesia, is the basis for the production of surface layers from aluminium oxide by means of duplex methods. It enables the control of process parameters, which allows, within some limits, programming the selected functional properties of the obtained upper layers. According to the method proposed, anodising is conducted in a three-component water electrolyte that consists, of among others, sulphuric and oxalic acids as well as an addition of succinic acid. Research was carried out on the aluminium alloy $\mathrm{AlMg}_{2}$. The electrolyte temperature during anodising falls within the range $293-313 \mathrm{~K}$, whereas the anodic density of current was between $2 \mathrm{~A} / \mathrm{dm}^{2}$ and $4 \mathrm{~A} / \mathrm{dm}^{2}$. Such a range of temperatures means that the anodising process can be initiated at an ambient temperature. Tests of the structure and morphology of the surface of $\mathrm{Al}_{2} \mathrm{O}_{3}$ layers were conducted using a Philips XL30 scanning microscope (SEM).

An atomic force microscope (AFM) of the VEECO company, MULTOMODE model, operating in the standard contact mode, was used for the examination of the micro-unevenesses of the obtained oxide layers via the electrochemical method in three-component electrolytes after graphite saturation.

A DRON-2 diffractometer was used for an X-ray phase analysis of the obtained $\mathrm{Al}_{2} \mathrm{O}_{3}$ and duplex layers.

$\mathrm{Al}_{2} \mathrm{O}_{3}$ layers have a columnar (fibrous) structure, which is shown in Figure 1.

The technology of obtaining duplex layers based on aluminium oxide consists of a two-stage production 


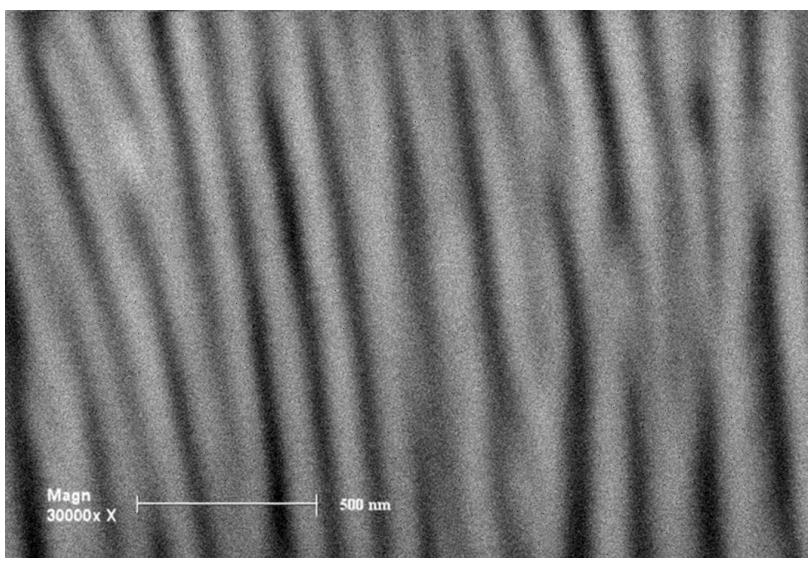

Figure 1: Cross-sectional SEM image a columnar-fibrous structure of an oxide layer

Slika 1: SEM-posnetek preseka stebrasto-vlaknaste zgradbe oksidne plasti

process. In the first stage, the base layer is produced via hard anodising in order to obtain the optimal structural and morphological properties (gradient structure and high porosity). Prior to the oxidation process, the samples are etched for $40 \mathrm{~min}$ in a $5 \%$ solution of $\mathrm{KOH}$ and next, in order to reverse the etching reaction, tinned for $10 \mathrm{~min}$ in a $10 \% \mathrm{HNO}_{3}$ solution. The etching and tinning processes are followed by rinsing in distilled water. In the first phase, the surfaces are subjected to anodic oxidation in an electrolyte composed of an aqueous solution of sulphuric, succinic and oxalic acid. Following anodising, the samples with an $\mathrm{Al}_{2} \mathrm{O}_{3}$ layer are rinsed in distilled water in order to rinse out the electrolyte. Graphite was introduced into the structure of the aluminium oxide during the thermal treatment in a solid medium consisting of graphite dust. Samples sprinkled with graphite dust are tightly closed in boxes and heated in an electric oven at the following temperatures: (343, 363, 383 and 403) $\mathrm{K}$ for $(24,36$ and 48) h for each temperature. When the process ends, the samples were cleaned with compressed air.

\section{RESULTS AND DISCUSSION}

A fibrous structure causes micro- and nanoporosity of the $\mathrm{Al}_{2} \mathrm{O}_{3}$ layer. An example of the morphology of the surface of the $\mathrm{Al}_{2} \mathrm{O}_{3}$ layers, obtained via hard anodising, is shown in Figure 2.

The measurement results of the diameter of fibres and the number of fibres and nanopores are juxtaposed in Table 1.

Tests of the structure of the duplex-type layers after graphite infiltration were conducted using a transmission electron microscope. The results of the tests of the structure of duplex-type layers after carbonisation of the $\mathrm{Al}_{2} \mathrm{O}_{3}$ layers via saturation are presented in Figures 3 and 4. An analysis of the chemical composition was also made using a Philips XL30 scanning electron microscope with an EDS attachment. The results of the tests of

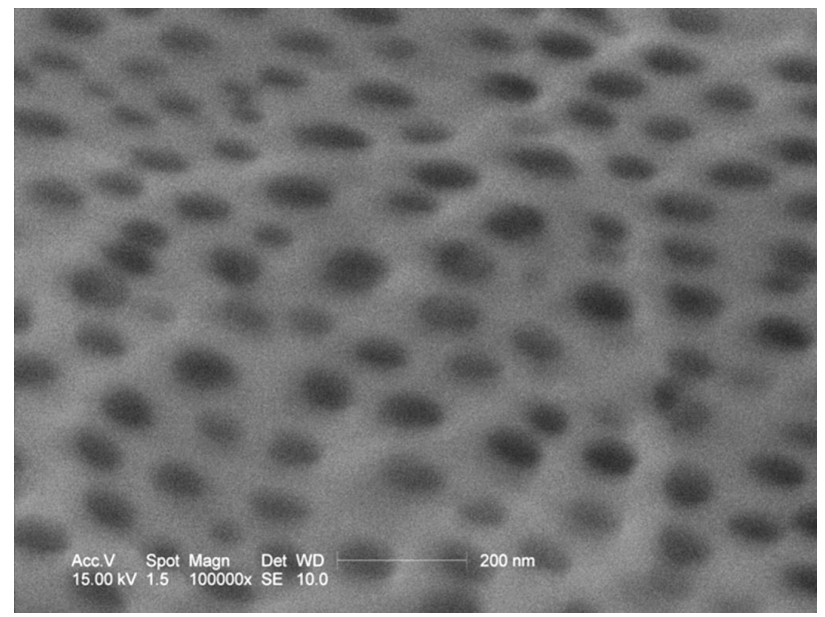

Figure 2: SEM image of nanopores in the $\mathrm{Al}_{2} \mathrm{O}_{3}$ layer Slika 2: SEM-posnetek nanopor v plasti $\mathrm{Al}_{2} \mathrm{O}_{3}$

Table 1: The dimensions, the number of fibres and the number of pores

Tabela 1: Dimenzije, število vlaken in število por

\begin{tabular}{|c|c|c|c|}
\hline $\begin{array}{c}\text { Production } \\
\text { parameters }\end{array}$ & $\begin{array}{c}\text { Fibre diameter } \\
(\mathrm{nm})\end{array}$ & $\begin{array}{c}\text { Number of } \\
\text { fibres per } \mathrm{mm}^{2}\end{array}$ & $\begin{array}{c}\text { Number of } \\
\text { pores per } \mathrm{mm}^{2}\end{array}$ \\
\hline $\begin{array}{c}\mathrm{j}=2 \mathrm{~A} / \mathrm{dm}^{2} \\
\mathrm{t}=293 \mathrm{~K}\end{array}$ & 100 & $100 \times 10^{6}$ & $200 \times 10^{6}$ \\
\hline $\begin{array}{c}\mathrm{j}=2 \mathrm{~A} / \mathrm{dm}^{2} \\
t=303 \mathrm{~K}\end{array}$ & 120 & $64 \times 10^{6}$ & $128 \times 10^{6}$ \\
\hline $\begin{array}{c}\mathrm{j}=2 \mathrm{~A} / \mathrm{dm}^{2} \\
\mathrm{t}=313 \mathrm{~K}\end{array}$ & 200 & $25 \times 10^{6}$ & $50 \times 10^{6}$ \\
\hline $\begin{array}{c}\mathrm{j}=3 \mathrm{~A} / \mathrm{dm}^{2} \\
\mathrm{t}=293 \mathrm{~K}\end{array}$ & 110 & $81 \times 10^{6}$ & $162 \times 10^{6}$ \\
\hline $\begin{array}{c}\mathrm{j}=3 \mathrm{~A} / \mathrm{dm}^{2} \\
\mathrm{t}=302 \mathrm{~K}\end{array}$ & 140 & $49 \times 10^{6}$ & $98 \times 10^{6}$ \\
\hline $\begin{array}{c}\mathrm{j}=3 \mathrm{~A} / \mathrm{dm}^{2} \\
\mathrm{t}=303 \mathrm{~K}\end{array}$ & 160 & $36 \times 10^{6}$ & $72 \times 10^{6}$ \\
\hline
\end{tabular}
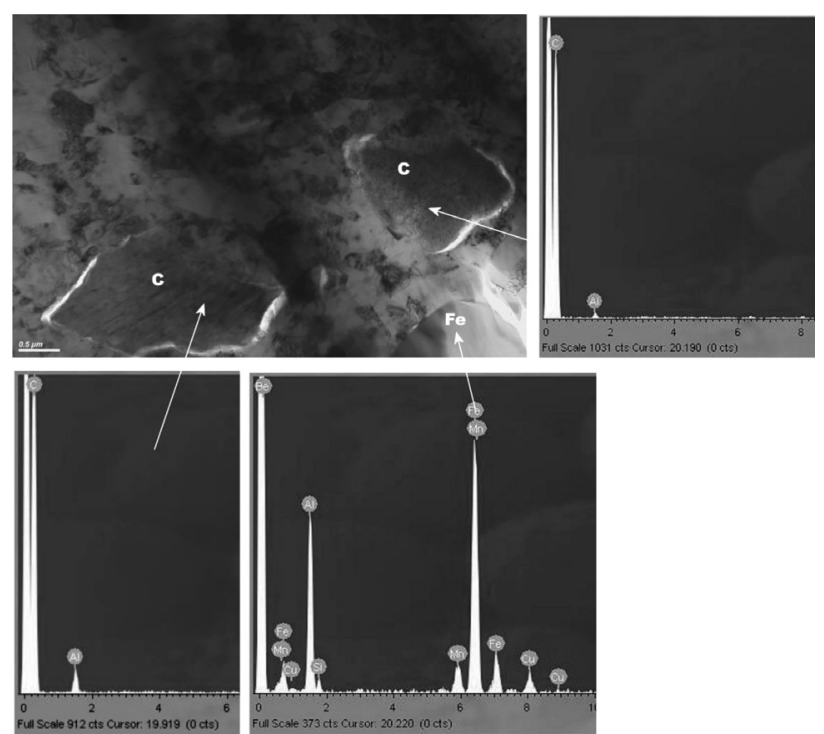

Figure 3: Top view of the surface of a duplex-type layer after saturation with graphite, with spectra (transmission microscope)

Slika 3: Slika površine dupleksne vrste plasti po nasičenju z grafitom, s spektri (presevni mikroskop) 

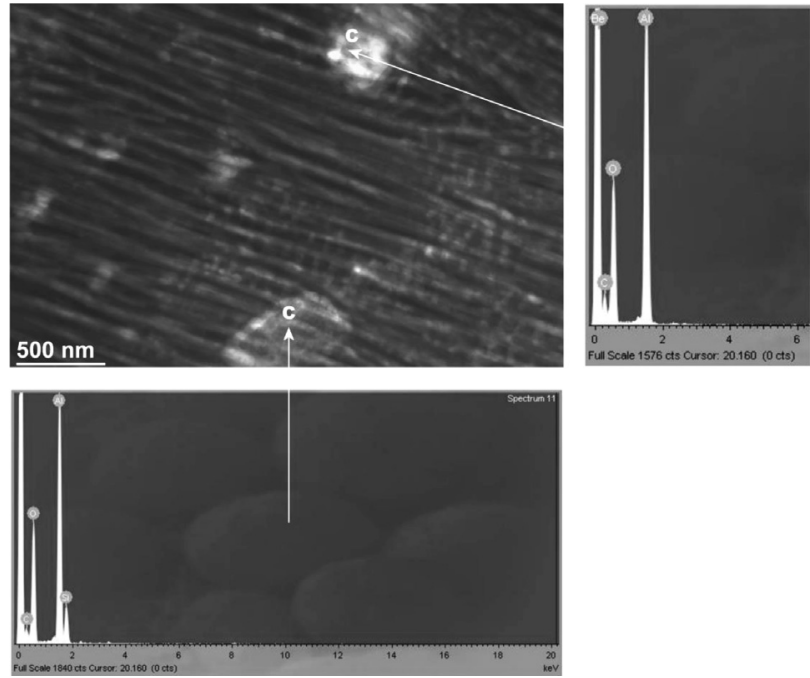

Figure 4: Cross-sectional of a duplex-type layer after saturation with graphite, with spectra (transmission microscope)

Slika 4: Presek dupleksne plasti po nasičenju z grafitom, s spektri (presevni mikroskop)

the change in the chemical composition of these layers obtained during carbonisation at the temperatures of $383 \mathrm{~K}$ are presented in Figure 5.

The structure of the duplex-type layers contains carbon and other precipitates, which are typical for the
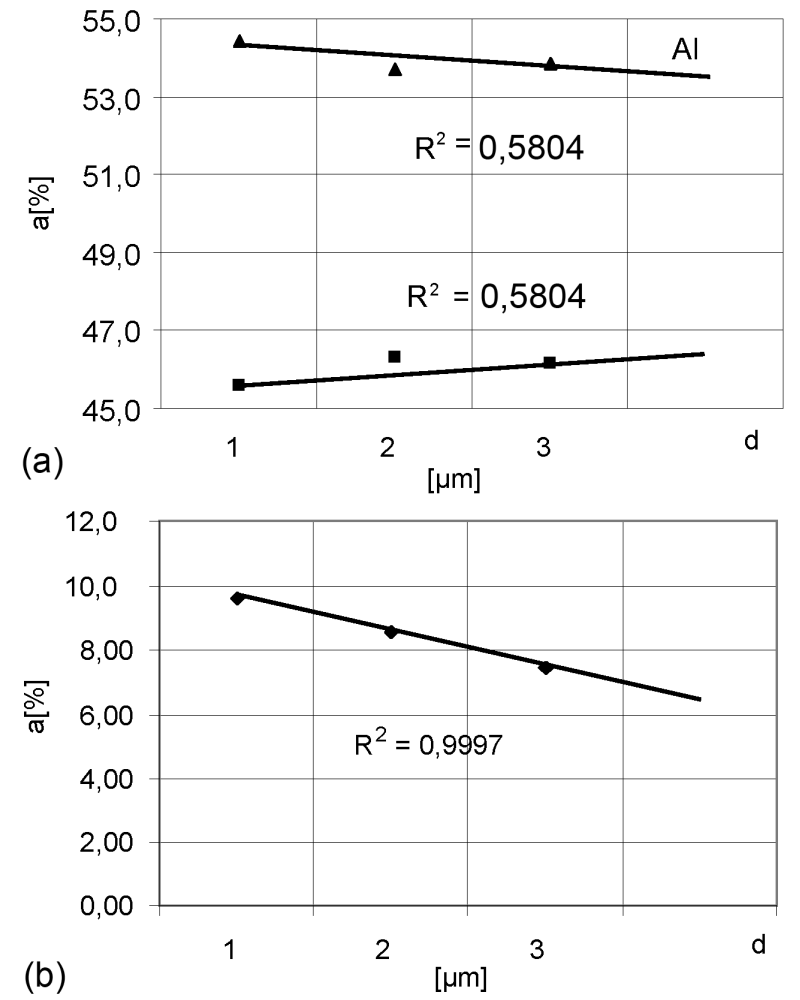

Figure 5: Changes in the chemical composition of duplex-type layers obtained after saturation at the temperature of $383 \mathrm{~K}$ : a) change in the oxygen and aluminium content, b) change in the graphite content

Slika 5: Spreminjanje kemijske sestave dupleksne plasti, dobljene po nasičenju na temperaturi $383 \mathrm{~K}$ : a) spreminjanje vsebnosti kisika in aluminija, b) spreminjanje vsebnosti grafita
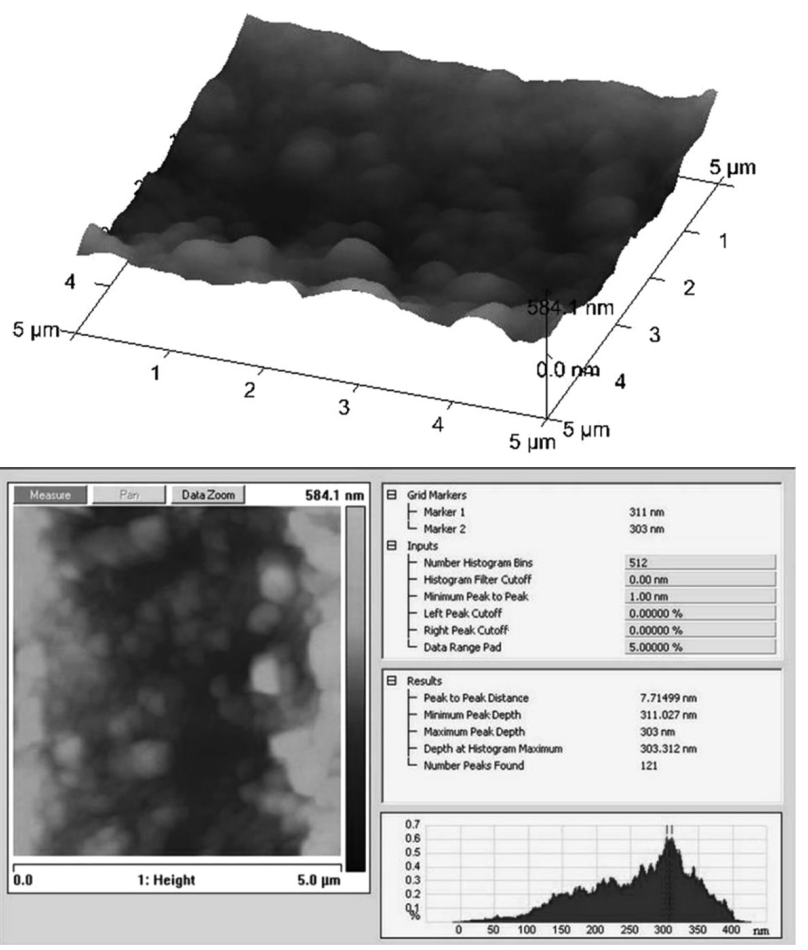

Figure 6: a) AFM images of the surface (3D) of duplex-type layers and b) micro-unevennesses of the surface, and a histogram; anodising process parameters: $j=3 \mathrm{~A} / \mathrm{dm}^{2}, T=303 \mathrm{~K}, t=1 \mathrm{~h}$; carburisation parameters: $T=343 \mathrm{~K}, t=24 \mathrm{~h}$

Slika 6: a) AFM-posnetek površine (3D) dupleksnih plasti in b) mikro-neravnine na površini in histogram s parametri procesa anodizacije : $j=3 \mathrm{~A} / \mathrm{dm}^{2}, T=303 \mathrm{~K}, t=1 \mathrm{~h}$; parametri naogljičenja: $T=343 \mathrm{~K}, t=24 \mathrm{~h}$

alloy, with additions of $\mathrm{Fe}, \mathrm{Mn}, \mathrm{Cr}$ and other elements. Carbon precipitates have a relatively weak connection with the matrix, as an envelope with numerous discontinuities forms around each carbon precipitate. Carbon precipitates are considerably larger than alloy precipitates, have micrometric dimensions, occur in groups and are composed of small grouped nanometric particles that form larger agglomerates. This means that there are nanometric particles inside micrometric ones. Therefore, the structure of carbon particles is complex.

The results of the tests of duplex-type layers obtained via the electrochemical method in three-component electrolytes after graphite saturation are presented in Figure 6. The following is shown: a) a topographic three-dimensional image, b) the geometric microstructure and a histogram.

X-ray diffractograms of the $\mathrm{Al}_{2} \mathrm{O}_{3}$ layer obtained on a crystalline alloy of $\mathrm{AlMg}_{2}$ aluminium and aluminium oxide, as well as a duplex layer are presented in Figure 7. An X-ray phase analysis has shown that the obtained $\mathrm{Al}_{2} \mathrm{O}_{3}$ layers are amorphous and also contain two peaks characteristic for the crystalline form of Kappa $\mathrm{Al}_{2} \mathrm{O}_{3}$, a phase of an indeterminate structure type, entered into the crystallographic data catalogue under the number 04-0878. A very strong typical peak from the graphite phase called chaolite (22-1069) is also present. 

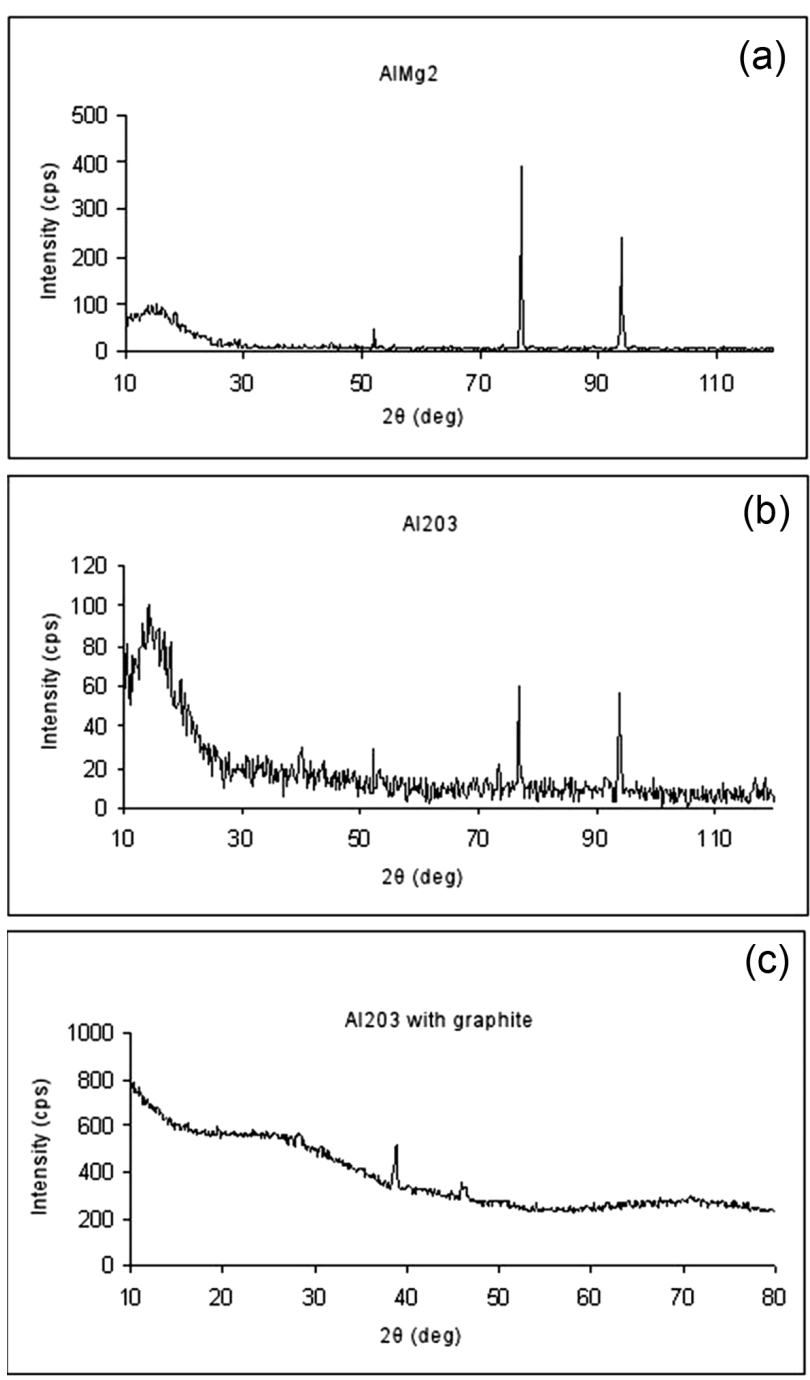

Figure 7: XRD spectra of the: a) substrate, b) aluminium oxide and c) a duplex layer

Slika 7: Rentgenogram: a) podlaga, b) aluminijev oksid in c) dupleksna plast

The porosity of the $\mathrm{Al}_{2} \mathrm{O}_{3}$ layers has a significant influence on their properties, including their wear resistance, the capacity for the sorption of lubricants, the possibility of a sliding film forming from a plastic (containing graphite) and first of all the susceptibility to further modification, which is used for obtaining layers via the duplex method. It is the micro- and nanoporosity of the $\mathrm{Al}_{2} \mathrm{O}_{3}$ layer that was used during the second stage of the dual technology to form duplex-type surface layers. The second technology used to produce duplextype layers consisted of infiltration with graphite. Owing to this, it will become possible to fill the above-described structure of the $\mathrm{Al}_{2} \mathrm{O}_{3}$ layer that is obtained via hard anodising with graphite.

\section{CONCLUSIONS}

The technology of obtaining aluminium-oxide-based duplex layers consists involves a two-stage production process. In the first stage, the base layer is produced via hard anodising in order to obtain optimal structural and morphological properties (gradient structure and high porosity). Following anodising, the samples with an $\mathrm{Al}_{2} \mathrm{O}_{3}$ layer are rinsed in distilled water in order to rinse out the electrolyte. Graphite was introduced into the structure of aluminium oxide during the thermal treatment in a solid medium consisting of graphite dust.

The structure of the duplex-type layers contains carbon precipitates and other precipitates, which are typical for the aluminium alloy, with additions of $\mathrm{Fe}$, $\mathrm{Mn}, \mathrm{Cr}$ and other elements. Carbon precipitates have a relatively weak connection with the matrix, as an envelope with numerous discontinuities forms around each carbon precipitate.

Surface layers obtained via the duplex method can have better wear resistance, a lower friction coefficient used to cover cylinders of lubricant-free compressors, pneumatic servo-motors or shock absorber components due to the increase of mechanical properties and the increased graphite content in the structure of the layers (which causes a decrease in the motion resistance of the kinematic nodes). The obtained aluminium-oxide-based, duplex-type surface layers fully confirm the usefulness of the new surface-treatment technologies in increasing the operational durability of the sliding couples of piston machines.

\section{REFERENCES}

${ }^{1} \mathrm{~W}$. Skoneczny, Model of structure of $\mathrm{Al}_{2} \mathrm{O}_{3}$ layer obtained via hard anodizing method, Surface Engineering, 17 (2001), 389-392, doi:10.1179/sureng.026708401101518060

${ }^{2}$ W. Skoneczny, J. Jurasik, A. Burian, Investigations of the surfaces morphology of $\mathrm{Al}_{2} \mathrm{O}_{3}$ layers by atomic force microscopy, Materials Science Poland, 3 (2004), 265-278

${ }^{3}$ T. Kmita, W. Skoneczny, Gradient layers on aluminum alloys created electrolytically, Chemical and Process Engineering, 26 (2005), 735-744

${ }^{4}$ T. Kmita, J. Szade, W. Skoneczny, Gradient oxide layers with an increased carbon content on en AW-5251 alloy, Chemical and Process Engineering, 29 (2008), 375-387

${ }^{5}$ W. Skoneczny, M. Bara, Aluminum oxide composite layers obtained by the electrochemical method in the presence of graphite, Material Science Poland, 25 (2007) 4, 1053-1062

${ }^{6}$ M. Bara, W. Skoneczny, M. Hajduga, Ceramic-graphite surface layers obtained by the duplex method on an aluminum alloy substrate, Chemical and Process Engineering, 30 (2009), 431-442

${ }^{7}$ S. Jeong, H. Hwang, S. Hwang, K. Lee, Carbon nanotubes based on anodic aluminum oxide nano-template, Carbon, 42 (2004), 2073-2080, doi:10.1016/carbon 2004.04.015

${ }^{8}$ K. Wada, T. Shimohina, M. Yamada, N. Baba, Microstructure of porous anodic oxide films on aluminum, Journal of Materials Science, 21 (1986), 3810-3816, doi:10.1007/J.MSBF00553432

${ }^{9}$ J. Mikulskas, S. Joudkazis, S. Jagminas, S. Meskins, J. G. Dumas, J. Vaitkus, R. Tomasiunas, Aluminum oxide film for 2D photonic structure; room temperature formation, Optical Materials, 17 (2001), 343-346, doi:10.1016/Opt.MatS0925-3467(01)00100-8

${ }^{10}$ J. De Leat, H. Terryn, J. Vereecken, Development of an optical model for steady state porous anodic films on aluminium formed in phosphoric acid, Thin Solid Films, 320 (1997), 241-252, doi:10.1016/S0040-6090(97)00741-4 
${ }^{11}$ M. J. Bartolome, V. Lopez, E. Escudero, G. Caruana, J. A. Gonzales, Changes in the specific surface area of porous aluminium oxide films during sealing, Surface \& Coatings Technology, 200 (2006), 4530-4537, doi:10.1016/j.surfcoat.2005.03.019

${ }^{12}$ V. Lopez, E. Otero, A. Bautista, J. Gonzales, Sealing of anodic films obtained in oxalic acid baths, Surface and Coatings Technology, 124 (2000), 76-84, doi:10.1016/S0257-8972(99)00626-X 